\title{
Visions, beliefs, and transformation: exploring cross-sector and transboundary dynamics in the wider Mekong region
}

\author{
Alex Smajgl $^{1,2}, \underline{\text { John R. Ward }}^{1,2}, \underline{\text { Tira Foran }}^{2}, \underline{\text { John Dore }}^{3}$ and Silva Larson $^{2,4}$
}

\begin{abstract}
Policy and investment decisions in highly connected, developing regions can have implications that extend beyond their initial objectives of national development and poverty reduction. Local level decisions that aim to promote trajectories toward desirable futures are often transformative, unexpectedly altering factors that are determined at higher regional levels. The converse also applies. The ability to realize desirable local futures diminishes if decision-making processes are not coordinated with other influential governance and decision levels. Providing effective support across multiple levels of decision making in a connected, transformative environment requires (a) identification and articulation of desired outcomes at the relevant levels of decision making, (b) improved understanding of complex cross-scale interactions that link to potentially transforming decisions, and (c) learning among decision makers and decision influencers. Research implemented through multiple participatory modalities can facilitate such relevant system learning to contribute to sustainable adaptation pathways. We test application of a systematic policy engagement framework, the Challenge and Reconstruct Learning or ChaRL framework, on a set of interdependent development decisions in the Mekong region. The analysis presented here is focused on the implementations of the ChaRL process in the Nam Ngum River Basin, Lao People's Democratic Republic and the Tonle Sap Lake and environs, Cambodia to exemplify what cross-scale and cross-sectoral insights were generated to inform decision-making processes in the wider Mekong region. The participatory process described aligns the facilitated development of scenarios articulating shared future visions at local and regional levels with agent-based simulations and facilitates learning by contrasting desired outcomes with likely, potentially maladaptive outcomes.
\end{abstract}

Key Words: complexity; development; Mekong; participatory research

\section{INTRODUCTION}

Regions can be analyzed as dynamic and coupled socialecological systems, which can vary in their ability to incorporate and adapt to change (Berkes et al. 2003, Lebel et al. 2006, Maru 2010). This ability contributes to the resilience of a socialecological system (Walker et al. 2004). Anthropogenic and biophysical influences can also transform a region, which implies a fundamental and potentially irreversible alteration of the system attributes and function (Gunderson and Holling 2001, Walker et al. 2004). A region where development investments have catalyzed wide scale transformation is the Mekong region.

The Mekong region (Dore 2003, ADB 2011) comprises all or part of six sovereign nations, where policy decisions and development investments are made at subnational, national, and supranational levels. The region is increasingly connected and large-scale development investments in one area can trigger ripple effects throughout the region, as investment flows shift, migration flows change, or hydrological flows are altered. Understanding the combined effect of large-scale development investments and climate change is critical for sustainable development. For instance, the effectiveness of adaptation strategies to climate change in and around Cambodia's Great Lake, the Tonle Sap, will be influenced by current and proposed hydropower investments in Lao People's Democratic Republic (PDR) and Yunnan, China (Lauri et al. 2012, ICEM 2013, Keskinen et al. 2013, Zomer et al. 2014).

Exploration of the impacts of policy decisions in Mekong countries is often confined to specific sectoral and national boundaries excluding explicit consideration of transboundary and cross-sectoral impacts (Dore 2003, Hirsch and Jensen 2006, Molle et al. 2009). Sectoral and national isolation are common outcomes, generating unintended consequences that remain outside the scope of deliberations unless cross-sector and crossscale dynamics are identified, specified, and explored (Smajgl 2003, 2009).

Specifically, national and local decision making can alter the trajectories of factors influential at a larger regional level, such as human migration, the distribution and scale of financial investments, fish migration, or river sediment transportation. Changes in regional drivers can stimulate feedbacks influencing the initial local decision-making situation. For example, Baird (2014) and Scott (2009) contend that a legacy of political alliances, cultural biases, and tenuous property rights have underpinned national programs of land concessioning, reinforced and legitimized by claims of a need for "economies of scale investment." Increased migration between regions affected by land concessions and urban centers is one of several possible responses to land and livelihood loss cited by interviewed households in the Nam Ngum and Tonle Sap case studies. Understanding such cross-scale dynamics and feedback loops is important for decision making at various levels, as, for example, when feedback loops from the wider region create important secondary or tertiary impacts at the local level. The need for an improved understanding of such complex dynamics emphasizes the importance of an effective science-policy interface.

Winter (1966:7) proposes that "policy brings to statement what is judged to be possible ... (and) is the nexus of fact, value and ultimate meaning in which scientific, ethical and theological-

${ }^{1}$ MERFI Mekong Region Futures Institute, ${ }^{2}$ CSIRO Land and Water Flagship, ${ }^{3}$ DFAT Australian Aid, Australian Embassy, Bangkok, Thailand, ${ }^{4}$ College of Business, Law and Governance, Division of Tropical Environments and Societies, James Cook University 
philosophical reflections meet." The ability for science to effectively contribute to policy deliberations partially depends on the complexity of the system under consideration, the degree of factual reliability or uncertainty, both perceived and actual, the extent of contested values, and the capacity of affected interests to negotiate competing claims (Hisschemöller and Hoppe 1996, Hoppe 2005, Pielke 2007, Sen 2009). Laswell (1971) emphasized the interdependence of knowledge contributions and value classes in a context of policy argumentation, challenging the efficacy of linear instrumental and conceptual models to explain sciencepolicy interactions and the willingness of decision makers to utilize scientific knowledge. Consistent with Laswell and focused on rural agricultural development, Clay and Schaffer (1986:192) argue a more plausible policy process would recognize that “... the whole life of policy is a chaos of purposes and accident. It is not at all a matter of the rational implementation of the so-called decisions through selected strategies."

Existing conceptualizations distinguish science-policy deliberations into for example, structured versus unstructured problems by locating them according to the dual dimensions of either ethical or empirical uncertainty and the degree of value consensus (Funtowicz and Ravetz 1993, Hisschemöller and Hoppe 1996, Pielke 2007). Structured problems represent relative certainty of salient, valid knowledge coupled with concordant values, beliefs, and norms of affected interests. Standardized methods and analytics are generally clearly defined for structured problem resolution and decision making tends to be unilateral. Conversely, unstructured problems are characterised by high knowledge/ factual uncertainty coupled with value conflict and poorly defined analytical resolutions, representing a class of problem regularly encountered in for example energy security and natural resource development decisions. Decision makers are also subject to bounded rationality (Simon 1972), cognitive biases and constraints (Kahneman 2011), a reliance on often firmly entrenched heuristics (Gigerenzer and Todd 2001), and divergent but valid rationalities (Faucheux et al. 1995, Kollock 1998, Größler 2004, Sen 2009) when confronted with unstructured problems and complex systems.

Clay and Schaffer (1986), Funtowicz and Ravetz (1993), Hisschemöller and Hoppe (1996), Sterk et al. (2009), and Stirling (2010) argue that decision makers regularly deploy strategies to reduce the complexity of policy choice arenas, avoiding scrutiny of proposed initiatives and limiting the exploration of alternatives that correspond with stated objectives. Containment biases that either limit or omit the representation of contested values, or restrict knowledge and arguments to those that correspond with criteria acceptable to current political beliefs are common strategies. Gasper and Apthorpe (1996), Shore and Wright (1997), and Cornwall (2007) contend that containment is a function of existing power relations, biasing social values and actions, framing problems and policy solutions, and thus legitimizing certain knowledge, actions, and actors, while delegitimizing others (Leach et al. 1999, Friend and Moench 2013).

Participatory research approaches are increasingly utilized to (1) establish an effective policy-science interface within complex, unstructured problems, (2) improve system learning, and (3) resist attempts to avoid or constrain policy deliberations. Participatory research is a very diverse field, largely applied in the domains of public health, environmental management, and education (Cornwall and Jewkes 1995). The common denominator for participatory approaches is that knowledge and attendant influence is not confined to the realm of science (Cornwall and Jewkes 1995). Cash et al. (2003) argue that for effective participation of affected interests, knowledge needs to be agreed as valid, salient, and legitimate. However, the degree to which community knowledge is commissioned (or omitted), what knowledge is exchanged, and what modalities are deployed between participating stakeholders varies widely (Barreteau et al. 2010). In cases with strong utilization of modeling the terminology mostly changes to participatory modeling. Voinov and Bousquet (2010) provide an excellent overview of participatory modeling while Barreteau et al. (2010) provide a useful framework for distinguishing different types of participatory modeling approaches. Most prominent examples for participatory research include community-based participatory research and action research (Cornwall and Jewkes 1995) and participatory action research (McIntyre 2008). It needs to be emphasized that both of these groups include a range of diverse approaches. Prominent approaches within participatory modeling include companion modeling (Bousquet et al.2006) and mediated modeling (van den Belt 2004).

Evaluation within the domains of participatory research and participatory modeling is largely limited to qualitative descriptions of impacts without a systematic and replicable experimental design. Ideally, participatory interventions are either compared with a control situation that is either not exposed to participatory activities; or elements in the decision-making context that do not find explicit consideration during the participatory process are monitored. It seems likely that the respective approach is deemed successful if targeted aspects of decisions or actions are amended while nontargeted, but monitored, aspects remain constant.

An additional evaluation dimension is the level of effectiveness. Multiple approaches can lead to a positive effect and it is desirable to qualify if one approach is more effective than another. Such a comparative perspective requires constant metrics across multiple participatory designs, which is difficult because metrics are process and objective specific (i.e., conflict resolution, learning, prediction), are context dependent (indicators related to health, education, resource use, knowledge), and on the level (i.e., community, governance). Differences in these dimensions make formal comparisons of alternative participatory modeling approaches difficult.

We test the application of a systematic science-policy engagement framework (the Challenge and Reconstruct Learning or ChaRL framework; Smajgl and Ward 2013a) on a set of interdependent development decisions in the Mekong region. The ChaRL framework is intended to address the deficit of formal evaluation and monitoring that is a general characteristic of participatory modeling approaches, particularly those concerned with unstructured policy deliberations. The primary objective of the participatory process is to engender and facilitate learning and as a corollary, better align intended development decisions with stated objectives and outcomes. Because learning is central to the process, the ChaRL framework utilizes changes in elicited beliefs and values as psychometric assessments. 
The analysis presented here is focused on the implementations of the ChaRL process in the Nam Ngum River Basin, Lao PDR, and the Tonle Sap Lake and its environs, Cambodia to exemplify what cross-scale and cross-sectoral insights were generated to inform decision-making processes in the Mekong region. The application of the framework focused on decisions concerned with the competing claims of food, water, and energy security. The methods included holistic scenario development, expert panel assessments, household livelihood surveys, and agent-based modeling. We provide relevant background on the Mekong region, followed by the theoretical background for the ChaRL framework and results from an implementation of the ChaRL. Although focused on the Nam Ngum River Basin and Tonle Sap we also introduce some of the transboundary implications of national development strategies. We conclude the discussion with an analysis of monitoring and evaluation data that is presented against the backdrop of other participatory approaches.

\section{THE MEKONG REGION}

There are many conceptualizations and constructs that define the Mekong: the river, the river basin, and the region. To set the context for the subsequent discussion, it is important to briefly introduce each.

There are many rivers in the wider Mekong region, but the iconic Mekong River is the epicentre of contemporary debates about water resources development in the Southeast Asian region. It is the longest river in Southeast Asia with an estimated length of $4909 \mathrm{~km}$ (Liu et al. 2007) making the Mekong the 12th longest river in the world and the 8th largest volumetric water flow.

The Mekong River Basin is approximately $800,000 \mathrm{~km}^{2}$ (IUCN et al. 2003). It comprises a very small percentage of the territory of China, $4 \%$ of Myanmar, $97 \%$ of Laos, $36 \%$ of Thailand, $86 \%$ of Cambodia, and $20 \%$ of Vietnam (MRC 2011), depicted in Figure 1 . There are about 70 million people living in the basin, but strikingly, there are only 9 cities with more than 100,000 people, with only $2 \%$ of the total area classed as urban or industrial. Approximately $42 \%$ of the land is still classified as forested, albeit this is $70 \%$ less than estimates of the original forest cover. A further $17 \%$ is classified as grasslands, savannah, and shrub-land, and $9 \%$ as wetlands, most, but not all in the delta. Cropping is estimated at $38 \%$ of land area, with less than $10 \%$ of this being irrigated (MRC 2011, ADB 2012).

The Mekong River and its basin are a subset of the region (Fig. 1). Across the region, local communities, governments, civil society organizations, business interests, donors, and international agencies affect and are affected by development decisions and seek effective representation of their often competing claims and interests.

We define the Mekong region to encompass the territory, ecosystems, people, economies, and politics of Cambodia, Laos, Myanmar, Thailand, Vietnam, and China's Yunnan Province (Mingsarn and Dore 2003). This region covers 2.3 million $\mathrm{km}^{2}$ and is home to more than 260 million people (ADB and UNEP 2004). Social and economic conditions, ethnicity, and negotiating powers all vary enormously. Aggregated national statistics do not adequately reflect the cultural and political contextual diversity of the region, nor the environmental complexity.
Fig. 1. The Mekong region and the five local studies considered in this study, including the two documented in this paper.

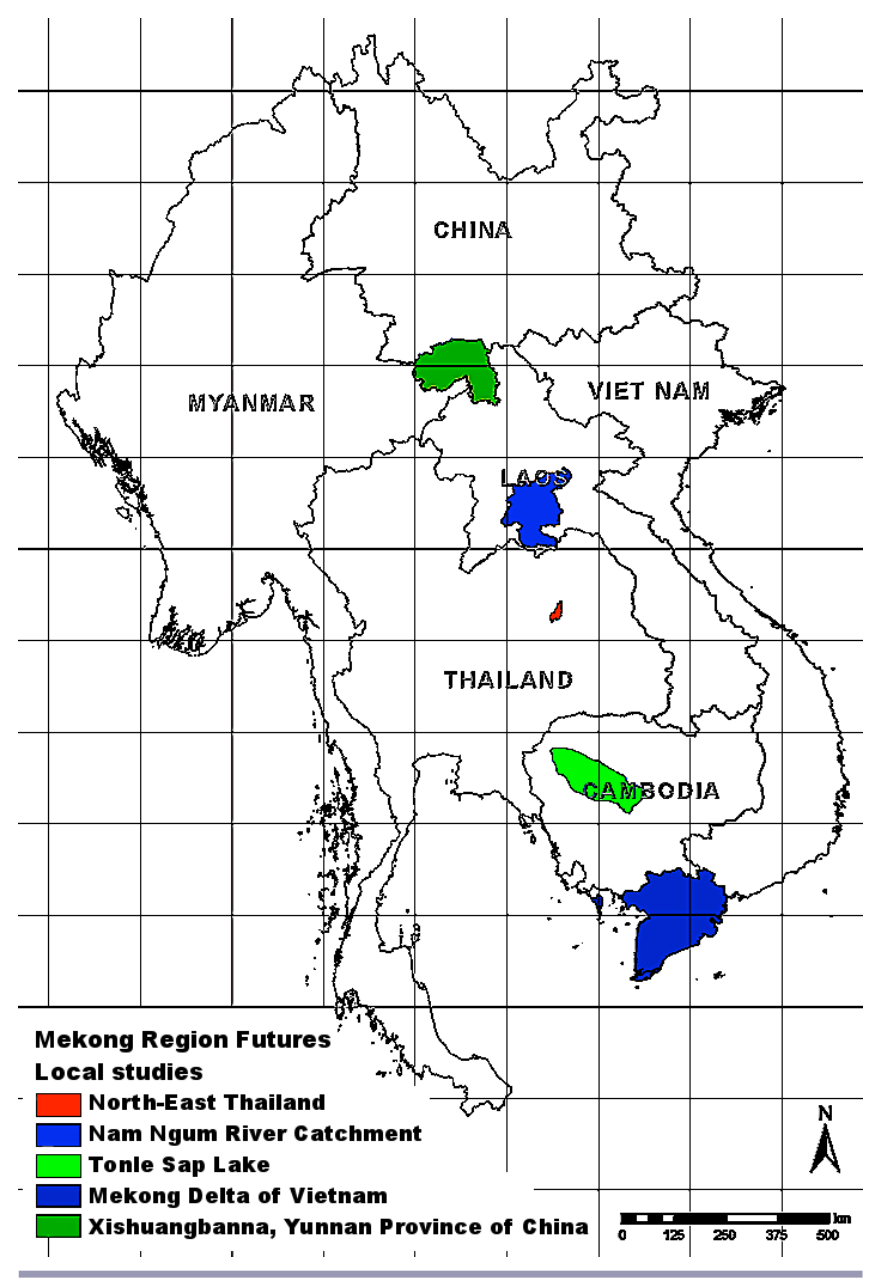

Significant parts of the region were in turmoil for much of the latter half of the 20th century as a result of a series of wars, internal strife, and external responses including the imposition of trade embargoes. Despite a tumultuous recent history, the Mekong region has had a period of relative inter-national peace since the early 1990s. There is a view that the region's abundant natural resources, such as water, forest, fisheries, biodiversity, minerals, and energy, provide enormous wealth creation possibilities. Proponents argue that the potential economic benefits from the use of these resources remain underutilized and untapped. However, current development and resource use has led to vastly disproportionate distribution of benefits and costs (Molle et al. 2009). One way of checking abuses is to ensure that alternative development trajectories, including the expansion of water-related initiatives, are scrutinised in the public sphere.

The Nam Ngum River Basin covers 7\% of the Lao PDR land area and is home to approximately 500,000 people, or $9 \%$ of total population (WREA 2008, Lacombe et al. 2014). Agricultural production in the Vientiane Plain produces the majority of food, where one-third of the nation's irrigated area is located and the site of potential irrigation expansion (Bartlett et al. 2012). Several 
irrigation projects up to 100,000 hectares are in various stages of planning as part of a larger government strategy to turn the basin into a national and regional production area for rice and vegetables (Jeuland et al. 2014). Additional discussions prevail on the diversion of flow from the Nam Ngum River to water-scarce areas in northeast Thailand via a large interbasin transfer (Bartlett et al.2012). The decision-making and planning processes in the Nam Ngum Basin are of regional relevance because the Nam Ngum River contributes, on average, 22 billion $\mathrm{m}^{3}$ to the Mekong River flow, or approximately $4.3 \%$ of total average flow. Contribution of the Nam Ngum to Mekong dry season flow, subject to hydropower dam operations, is in the order of $15-20 \%$ (Lacombe et al. 2014). Thus, decisions altering the water flow are likely to shift hydrological constraints downstream, a consideration influencing deliberations in the Tonle Sap Lake case study.

In the Tonle Sap Lake, sediment and nutrient flux and primary productivity are highly dependent on the annual Mekong River flood pulse, varying in size from $3000 \mathrm{~km}^{2}$ to $14,500 \mathrm{~km}^{2}$. The population is estimated at more than 1.8 million, $61 \%$ engaged in agriculture and $4.5 \%$ in fishing. The Tonle Sap plays a critical role in food production in Cambodia, particularly the annual fish catch estimated at between 290,000 to 430,000 tonnes (Van Zalinge et al. 2000). Keskinen et al. 2011 estimate that $80 \%$ of the Cambodian population are reliant on the Tonle Sap fish catch for critical protein source. Keskinen et al. $(2011,2013)$ and Kummu and Sarkkula (2008) estimate that the cumulative effects of upstream hydropower operations and attendant nutrient flux, potentially reduces the lake's primary productivity by up to $50 \%$. The effect on fisheries remains a subject of ongoing and vigorous debate.

\section{METHODS}

The Challenge and Reconstruct Learning framework (ChaRL) Improving decision makers' understanding of the possible implications that large-scale changes might have in the Mekong region requires an approach that effectively bridges research and policy. This work aims to achieve such system learning by implementing the ChaRL (see the schematic in Fig. 2) framework (Smajgl and Ward 2013a). The framework entails five key steps to facilitate learning, accomplished via a structured and sequenced set of facilitated participatory workshops.

Fig. 2. The ChaRL framework - Challenge and Reconstruct Learning (adapted from Smajgl and Ward 2013a).

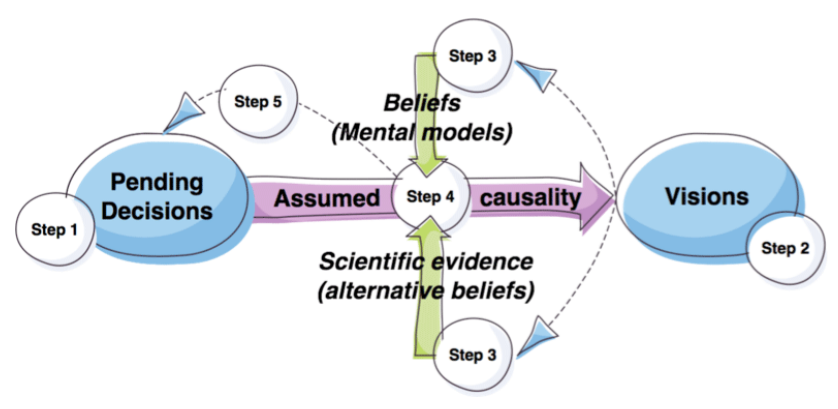

The five ChaRL steps define the structured process of formally questioning and measuring existing underlying assumptions (heuristics) and reconstructing revised assumptions within the understanding of a larger systems view. We understand such rational reconstruction in the tradition of Habermas (2005) as the key process of learning, which is facilitated as an exchange of intuitive knowledge.

Step 1 scopes out the context with the objectives, including the decision-making context and options, and the relevant success indicators as perceived by the decision makers. Inviting the relevant decision makers to codesign the research is critical to ensure high levels of engagement (Smajgl 2010).

In step 2 visions for a specified geographic location are developed as narratives of plausible futures desirable for all relevant stakeholders (Foran et al. 2013). This step might need to be implemented in multiple iterations if the set of decisions are likely to affect multiple action arenas, which demand separate facilitation. The iterative approach involves the presentation of visions from other locations or governance levels and invites the revision of the original vision draft, accounting for external implications and consequences. Shared visions are essential because otherwise participants revert to their sectoral goals when debating benefits of development strategies. Visions become normative benchmarks that are shared across competing sectoral interests.

During step 3 scientific evidence is presented to assess expected outcomes of contemplated decisions. During this step note takers formally record existing beliefs, expressed as statements that articulate perceived causal relationships held by decision makers.

Step 4 constitutes the core learning step because previously recorded beliefs are explicitly compared (a) with each other and (b) with scientific evidence. Revealed contrasts are discussed in the context of how pending decisions will contribute (or not) to the realization of desirable visions articulated in Step 1. This process facilitates the reconstruction of underpinning heuristics and assumptions (the set of beliefs) against the backdrop of desired futures. The process aims to guide the discussion session toward an action plan that first accounts for revealed disparities between beliefs and desired futures, and second has sufficient promise to achieve the desired future and avoid nondesired, maladaptive outcomes. Step 5 constitutes a specific set of actions, debated, revised, and agreed, to realize the participants' desired objectives and future vision.

Compared with other participatory approaches three key differences can be outlined. First, ChaRL develops shared visions as normative benchmarks to circumvent competitive sectoral interests. Second, in the wider domain of participatory research most approaches work at the level of households or individuals, whereas ChaRL is designed for multilevel governance interactions. Third, in contrast to most participatory research, ChaRL does not explicitly elicit stakeholder knowledge and treat it as scientific evidence. Instead, both stakeholder and scientific knowledge is elicited or produced, but kept separate to develop contrasts to facilitate learning in the final step 5 workshop. This is also a key difference to most participatory modeling approaches, which aim to translate stakeholders' perception of 
the world into model design, as implemented in companion modeling, mediated modeling, or participatory simulation. The main reason for building the models based on primary data, i.e., information provided by household survey, rainfall data, or crop price ranges, and expert knowledge only is to maximize the model's potential to challenge participants' beliefs. Designing the model based on participant beliefs would reinforce existing beliefs and heuristics, constraining debate to align prevailing beliefs instead of potentially contradicting existing beliefs. Maintaining the independence of the two knowledge pools, allows for a controlled introduction of evidence and comparative analysis.

This does not imply that in all instances the scientific evidence is accepted as the superior understanding during the participatory process. Instead, scientific evidence is offered as an alternative viewpoint rather than a singular definitive result (Stirling 2010), which stakeholders often reject as unrealistic. These differences question the classification of the ChaRL framework as a participatory approach because it may not meet the criteria that constitute some definitions (Barreteau et al. 2010). However, shifting the project design into the hands of decision makers, allowing them to determine the scientific focus and enabling participants to use the methods and results are typical characteristics of participatory research.

\section{Multilevel participatory process}

The ChaRL framework was implemented in a series of workshops conducted in five of the countries that comprise the Mekong region (see Fig. 3 ). Step 1 was implemented in 2010 as a series of stakeholder meetings and small design workshops to specify the decision-making context and design the research project. Three relevant decision-making levels emerged from this process: the provincial, the national, and the regional. Because of broader policy considerations and operational feasibility, development decisions were restricted to Lao PDR, Cambodia, Thailand, Vietnam, and Yunnan, excluding Myanmar. Decision makers from each country were invited to identify an impending investment or development decision they perceived as highly important for achieving national development goals. Decisions that had a low possibility to trigger regional ripple effects were excluded from further discussions. The following decisions emerged from implementing Step 1 of ChaRL (Fig. 1) in the Mekong region:

1. Government payments for the conversion of rubber monocultures in Xishuangbanna, Yunnan;

2. Large scale irrigation in the Nam Ngum River Basin in Lao PDR;

3. Cross-basin water diversion in Hua Sai, northeast Thailand and the implications of energy crops;

4. The effect of upstream dams on the Tonle Sap Lake and environs in Cambodia;

5. The impact of sea-level rise and potential adaptation options on Vietnam's Mekong Delta.

This required the implementation of the ChaRL framework in five locations with national, provincial, and local stakeholders. In addition to these five processes, a parallel series of workshops was conducted to consider relevant supra-national decision makers.
The multimethod approach aimed to inform decision making and planning processes across the wider Mekong region, bringing subnational, i.e., local level, and supra-national interests into interlinking participative processes, the poly-centric governance principle (Ostrom 2010).

Fig. 3. Design and implementation steps in the Challenge and Reconstruct Learning (ChaRL) participatory process.

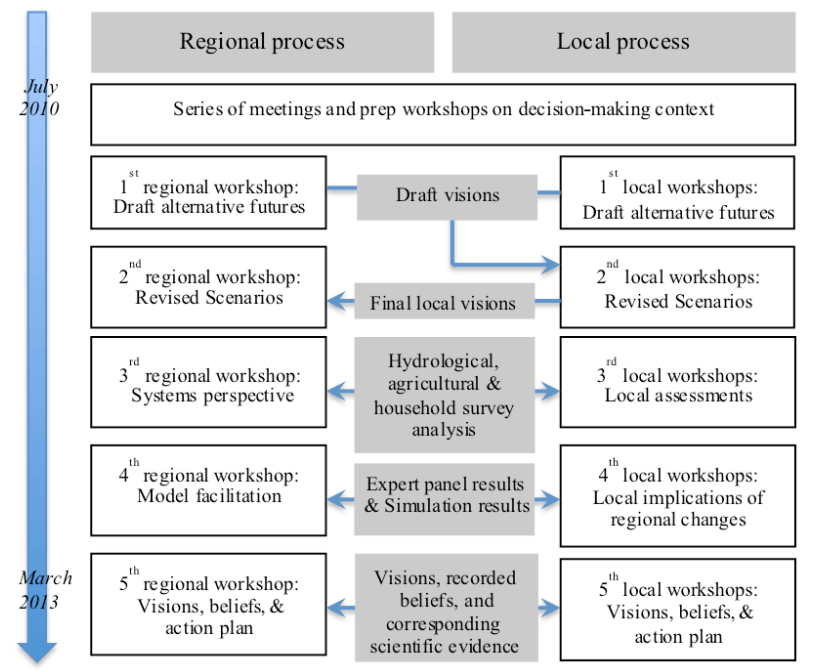

The household survey

A representative sample of 1000 households (20 randomly selected households from 50 randomly selected villages) was drawn from the three Tonle Sap livelihood zones (Keskinen et al. 2011) and Nam Ngum River Basin provinces, including upland catchments and the Vientiane plain. The process of translation and adaptation of survey instrument followed WHO guidelines recommending the steps of forward translation; expert panel back-translation; pretesting and cognitive interviewing (WHO 2011). Trained enumerators interviewed household members, following a pretested questionnaire translated into Khmer and Lao (Ward and Poutsma 2013). Responses were elicited to data classes summarized as follows: household composition and demographic attributes of all household members; household assets; net household income aggregated from primary, secondary, and tertiary dry and wet season agricultural production, up to three nonfarm activities and remittances; the perceived likelihood of occurrence and impact of factors influencing household livelihood status; the main attributes of self-assessed well-being; human value orientations that act as guiding life principles and the foundation of beliefs and behaviors; and intended adaptation strategies and future behavior in response to questions that framed hypothetical, specified changes in livelihood circumstances and factors (Ward and Poutsma 2013).

The Mekong region simulation (Mersim) model

The description of the agent-based model Mekong region simulation (Mersim; Smajgl et al. 2013) follows the Overview Design concepts - Details (ODD) protocol (Grimm et al. 2006, 2010). 
Purpose of the model: The simulation model aims to contribute to the learning-focused ChaRL framework by providing insights in more complex social-ecological interactions.

State variables: Household income, household attributes, and selfselected livelihood factors, household location, land cover, subsistence production, and poverty rate.

Emergence: Poverty rate over time, spatial poverty patterns, livelihood changes, and land-use patterns.

Adaptation and objective: Household agents respond to income levels that result from paid labor or agricultural activities. Households' objectives are implicit to their behavioral response functions (or rules). Modeled agents respond to livelihood related changes based on intentional data elicited in the large-scale surveys. No additional optimization or satisficing assumption is implemented. As a corollary, household expectations and learning are not explicitly represented but implicitly captured by the empirically derived response strategies.

Stochasticity: Most parameters are assumed to be stochastic to resemble more realistic model assumptions, including crop prices, productivity, wages, and rainfall.

Initialization: The Mersim model utilizes five sets of GIS data: (1) administrative boundaries down to administrative villages, (2) soil data, (3) land-cover data, (4) rainfall projections, and (5) a digital elevation model. These datasets were used to specify the artificial landscape while household attributes and behavioral responses were parameterized based on the household survey.

Submodels: Household income is calculated in weekly steps as the sum of all livelihood activities that all household members engage in. This includes the monetization of subsidence production to avoid a misleading, underestimated quantification of poverty. Poverty is calculated as the percentage of people within a (administrative) village below the official poverty line.

\section{Monitoring and evaluation}

Research impacts were evaluated by eliciting those causal beliefs that constitute major influences for key decision making agencies. Based on the theoretical underpinnings of the ChaRL framework we assume that systems learning would mobilize an amended set of participants' beliefs and value orientations (Smajgl and Ward 2013a).

The information treatments stakeholders experience during workshops 3 and 4 constitute new evidence that either aims to ground-truth assumptions on critical system variables or to introduce into the decision-making process higher levels of complexity. Stated beliefs, expressed as key causal statements (if $\mathrm{X}$ occurs then $\mathrm{Y}$ occurs), were recorded by formally trained observers during workshops 3 and 4. Training for all observers followed a specific, interactive, and consistent protocol. All revealed beliefs were explicitly presented during the fifth workshop and compared with scientific evidence. The final session and the discussion on how prior and alternative heuristics compare allows for eliciting evidence for research impact.

Individual value orientations of participants were elicited according to responses to the identical set of five human value scales and 15 scale items proposed by Stern et al. (1998), abbreviated from value scales originally developed by Schwartz
$(1992,1994)$ and described in Table 1. The five scale constructs measure individual levels of biocentricity, openness to change, conservatism or family security, altruism, and self-interest or egocentricity. Participants in the first, fourth, and fifth Nam Ngum and Tonle Sap workshops were invited to complete the written value item questionnaire. Responses were measured according to a 6-point numerical likert scale ranging from -1 for rating any values opposed to the principles that guide your life to 4 for rating a value of supreme importance as a guiding principle in your life. Questionnaire instructions suggested that there are usually no more than two scale items of supreme importance. The questionnaire response rate was approximately $75-95 \%$, depending on the workshop and location. However, cultural obligations of participants to attend the royal cremation of King Norodom Sihonouk meant only six questionnaires $(\mathrm{N}=45)$ were completed from the fifth Tonle Sap workshop.

\section{RESULTS}

\section{Nam Ngum River Basin, Lao PDR}

The second step of the ChaRL framework (Fig. 2, Visions), requires the development of visions with stakeholders related to the planning process. Participants in the Nam Ngum case study included the River Basin Committee Secretariat, Ministry for Natural Resources, and Environment's Department of Water Resources, community representatives, representatives of hydropower companies, NGOs, and provincial government actors.

Two sessions of holistic scenario workshops were held and produced a consistent set of desirable futures, expressed as small groups constructed storyline narratives. The visioning technique employed is described in Foran et al. (2013). The visioning was conducted in two iterations: an initial visioning step, ranking key influences according to the degree of perceived uncertainty and importance; followed by a second step in which participants were presented with draft visions from other local studies. Based on this input participants could revise their draft vision, acknowledging that transboundary effects shift the constraints assumed during the first visioning step. Key features of the final visions developed in the Nam Ngum comprised the following:

- Poverty reduced and livelihoods improved;

- Improved education and technical assistance;

- Protection of headwaters and forests;

- Development of industry and hydropower;

- Development of irrigation schemes;

- Access to new markets;

- Policies that are fair to both developers and communities;

- Effective community participation in all decisions;

- Promote cooperation and coordination;

- Equitable distribution of benefits and opportunities;

- Poverty reduction developments that avoid floods, and minimize social conflict and water pollution.

As a part of the fourth step of the ChaRL framework (participatory workshops 3 and 4 ) participants were exposed to 
Table 1. Comparison of the distribution of aggregated scale item scores: Tonle Sap workshop (WS) 1 compared with 4; and Nam Ngum workshop 4 compared with 5 .

\begin{tabular}{|c|c|c|c|c|c|c|}
\hline \multirow[b]{2}{*}{ Human values scale and scale item } & \multicolumn{3}{|c|}{ Tonle Sap } & \multicolumn{3}{|c|}{ Nam Ngum } \\
\hline & $\begin{array}{l}\text { WS } 1 \text { mean } \\
\text { (s.d) }\end{array}$ & $\begin{array}{l}\text { WS } 4 \text { mean } \\
\text { (s.d) }\end{array}$ & $\begin{array}{l}t \text { value } \\
\text { (relative } \\
\text { change in } \\
\text { mean diff) }\end{array}$ & $\begin{array}{l}\text { WS } 4 \text { mean } \\
\text { (s.d) }\end{array}$ & $\begin{array}{l}\text { WS } 5 \text { mean } \\
\text { (s.d) }\end{array}$ & $\begin{array}{c}t \text { value } \\
\text { (relative change } \\
\text { in mean diff) }\end{array}$ \\
\hline $\begin{array}{l}\text { Biocentric } \\
\text { Respecting the earth (harmony with other species) } \\
\text { Unity with nature (fitting into nature) } \\
\text { Protecting the environment (preserving nature) }\end{array}$ & $\begin{array}{l}17.77 \\
(0.44)\end{array}$ & $15.83(1.58)$ & $\begin{array}{l}6.20 * * \\
\text { Moderate } \\
\text { decrease }\end{array}$ & $15.33(1.46)$ & $14.3(2.11)$ & $\begin{array}{c}2.010^{* *} \\
\text { Small decrease }\end{array}$ \\
\hline $\begin{array}{l}\text { Open to change } \\
\text { A varied life (filled with challenge, novelty, and change) } \\
\text { Curious (interested in everything, exploring) } \\
\text { An exciting life (stimulating experiences) }\end{array}$ & $\begin{array}{l}16.18 \\
(2.16)\end{array}$ & $14.48(1.74)$ & $\begin{array}{c}2.91 * * \\
\text { Small } \\
\text { decrease }\end{array}$ & $14.52(1.69)$ & $13.70(1.77)$ & $\begin{array}{c}1.622 \\
\text { No difference }\end{array}$ \\
\hline $\begin{array}{l}\text { Conservative (family security) } \\
\text { Honoring parents and elders (showing respect) } \\
\text { Family security (safety for loved ones) } \\
\text { Self discipline (self restraint and resistance to } \\
\text { temptation) }\end{array}$ & $\begin{array}{l}17.82 \\
(0.53)\end{array}$ & $15.62(1.40)$ & $\begin{array}{c}7.60 * * \\
\text { Large } \\
\text { decrease }\end{array}$ & $16.52(1.17)$ & $15.78(1.48)$ & $\begin{array}{c}1.899^{*} \\
\text { Small decrease }\end{array}$ \\
\hline $\begin{array}{l}\text { Altruism } \\
\text { Social justice (correcting injustice, care for the weak) } \\
\text { Equality (equal opportunity for all) } \\
\text { A world at peace (free of war and conflict) }\end{array}$ & $\begin{array}{l}17.82 \\
(0.53)\end{array}$ & $15.66(1.47)$ & $\begin{array}{l}7.19 * * \\
\text { Large } \\
\text { decrease }\end{array}$ & $16.57(1.63)$ & $15.81(1.69)$ & $\begin{array}{c}1.564 \\
\text { No difference }\end{array}$ \\
\hline $\begin{array}{l}\text { Egocentric Self Interest } \\
\text { Authority (the right to lead or command) } \\
\text { Wealth (material possessions, money) } \\
\text { Influential (having an impact on people and events) }\end{array}$ & $\begin{array}{l}15.76 \\
(2.19)\end{array}$ & $14.62(1.68)$ & $\begin{array}{c}0.55 \\
\text { No difference }\end{array}$ & $14.33(2.11)$ & $13.11(2.98)$ & $\begin{array}{c}1.594 \\
\text { No difference }\end{array}$ \\
\hline Sum supreme importance ${ }^{\dagger}$ & $\begin{array}{l}12.00 \\
(1.78)\end{array}$ & $4.72(3.00)$ & $\begin{array}{l}10.35^{* *} \\
\text { Large } \\
\text { decrease }\end{array}$ & $6.10(2.95)$ & $3.7(2.79)$ & $\begin{array}{c}2.908^{* *} \\
\text { Small decrease }\end{array}$ \\
\hline
\end{tabular}

commissioned research results. A set of mixed methods was combined, including disciplinary methods (hydrological, agricultural, and livelihood related studies) and integrated methods (expert panel assessment [Smajgl and Ward 2013b] and agent-based modeling). Results from a water balance model were presented to address the question of how much water would be available for the further development of various parts of the Nam Ngum Basin under particular climate change/reservoir scenarios. Results largely confirmed expectations that more dry season water is available than required under debated future scenarios, focused on increased numbers of hydropower dams and expanded irrigation schemes (Lacombe et al. 2014). In a next step the results from the household survey were presented to shed light on households' current livelihoods, their livelihood motivations, and possible adaptation intentions in response to (a) irrigation expansion and (b) an economic crisis, where production decreased by $50 \%$ for five years. Respondents could select one option from four future livelihood strategies: either remain in their village and continue current livelihood activities (no intention to adapt); stay and adjust activities; migrate and continue with current activities; or move and replace current activities. A series of subsidiary questions elicited constraining and enabling factors that influenced a respondent's capacity to adapt. These results indicated that $65 \%$ of surveyed households expressed an intention to adapt when net profits halved over a period of five years or more. Additionally, $38 \%$ would migrate if industry employment was available. These responses indicated a relatively high willingness to adapt compared with other local studies.

An expert panel assessment of the water-food-energy nexus was presented (Smajgl and Ward 2013b) as an increment increasing the level of complexity. The assessment considered the combined impact of development throughout the Mekong region, including hydropower, irrigation, and climate change. Results emphasized the regional connectivity and the potential for (cumulative) transboundary impacts. Three results were most debated during the Nam Ngum workshop. First, food prices are likely to increase, putting more pressure on the poor. Second, the shift of water access between the Mekong countries will increase the potential for possible conflict. Third, energy prices are likely to increase further, in spite of increased hydropower development in the Nam Ngum River Basin. 
Fig. 4. Impact of planned, large-scale irrigation infrastructure on average poverty in six provinces in the Nam Ngum Basin, Lao PDR, compared with a business-as-usual scenario. Poverty is defined as percentage of people below the official poverty line. This includes households' income as well as their monetized subsistence production. The average is calculated across 200 model runs and across all households in each province.

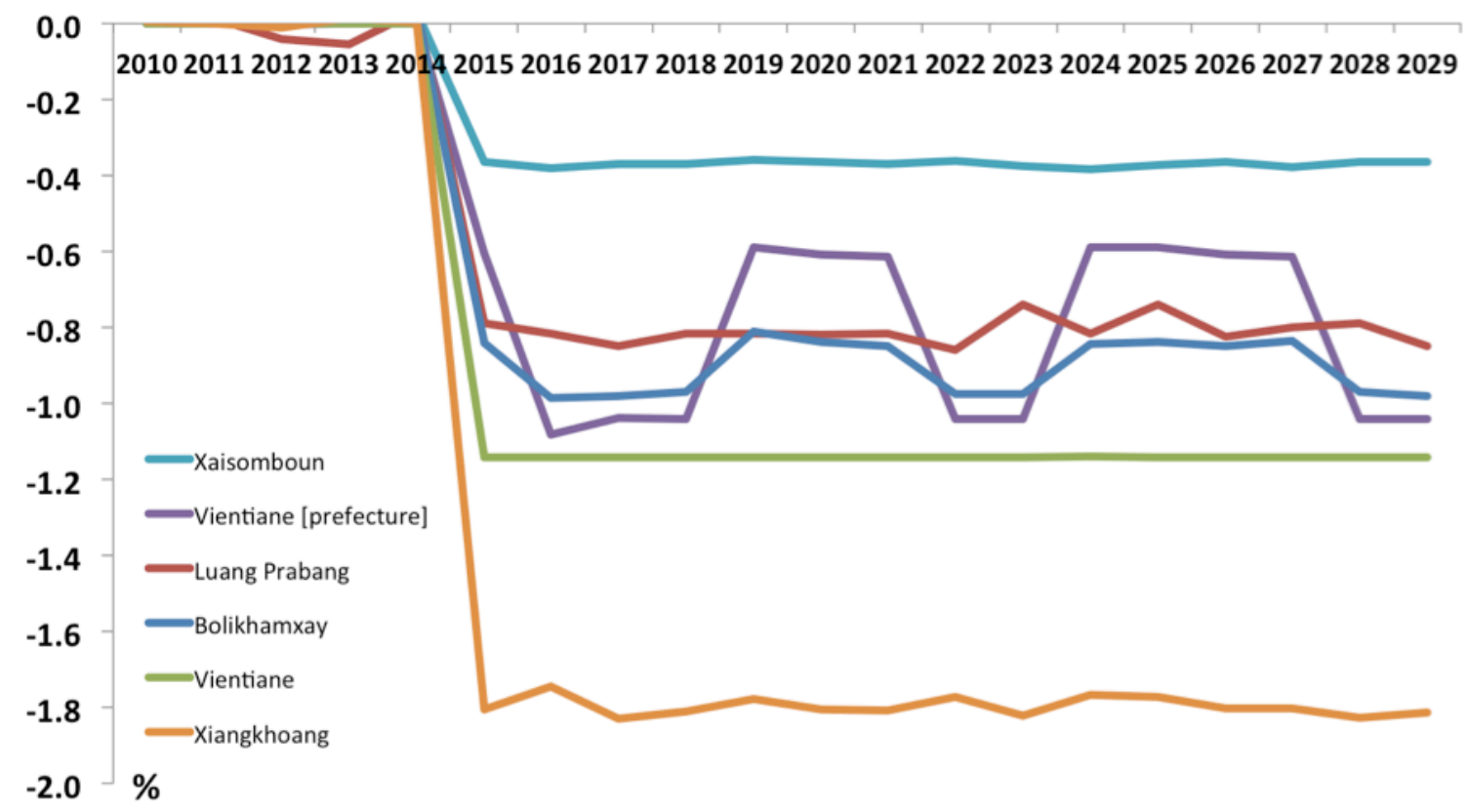

Finally the results from the agent-based Mekong region simulation (Mersim) model were presented. The model simulates household behaviors that are relevant to Nam Ngum Basin livelihoods and links them dynamically to environmental conditions (Smajgl et al. 2013). The additional insights this methodology provided relate to poverty. To the surprise of all participants, the modeling simulations suggested that poverty will not decline in response to the extension of irrigation schemes, although average provincial income is suggested to increase by 4\%-31\%, compared with current levels. Figure 4 shows poverty levels for most provinces within the Nam Ngum Basin are projected by the model to decrease by only $0.3 \%-1.8 \%$, compared with a scenario without investments in irrigation. Poverty levels decrease in Xieng Khouang province by approximately $1.8 \%$. It is assumed that irrigation becomes available from 2014 on, which explains the sudden change.

The controversial debate of this result became a pivotal workshop moment because poverty alleviation has been used as the principal argument for substantial investment in large-scale irrigation and new reservoirs. The simulation model helped reveal the simple insight that irrigation only benefits land owners; and the larger the landholding, the higher the additional benefit generated by access to irrigation infrastructure. Most poor people, however, do not own land and the participants concluded that even economic trickle effects do not seem likely in alleviating poverty levels because of current labor arrangements with neighbors and family members.

An additional insight emphasizes that poverty is temporally and spatially dynamic, which triggered an extensive and vigorous debate among participants. Modeling showed that irrigation and other interventions, i.e., industry employment, had successful uptake in four of the six districts, emphasizing the diversity of the Nam Ngum Basin. Additionally, expanded irrigation would noticeably alleviate poverty in only one province in three months, while many families would return to subpoverty line livelihoods for the remainder of the year.

Beliefs were recorded during the series of break-out group discussions that focused on debating the validity, saliency, and legitimacy of the presented research results. Beliefs, representing causal statements, are the key input for the fourth step of the ChaRL framework. Table 2 lists the most relevant beliefs recorded in the Nam Ngum Basin.

In preparation of the final workshop, beliefs were identified that could be challenged by scientific evidence created during the research conducted as part of the Nam Ngum Basin case study. Corresponding pairs of research results and beliefs were selected that had the potential to substantially challenge discordant visions and proposed decisions and actions. For the Nam Ngum Basin, the biggest challenge was the surprising lack of poverty reduction resulting from large-scale irrigation schemes, and the diverse impact of newly created industry employment across the various provinces. Based on the explicit debate focused on the discrepancy between initial beliefs and scientific evidence, stakeholders discussed alternative investments for the Nam Ngum Basin development plan. These alternatives shifted to small-scale irrigation in some high altitude districts, revised irrigation for the Vientiane floodplain, and a very targeted strategy for establishing manufacturing industries into two particular districts, 
Xaysomboun and Luang Prabang. This change articulated a clear move away from basin-wide solutions to an implementation of district specific development solutions (see Workshop 5 findings in Table 2).

Table 2. Beliefs recorded during the workshop process in the Nam Ngum, Lao PDR.

\begin{tabular}{|c|c|c|}
\hline Workshops $1 \& 2$ & Workshops $3 \& 4$ & Workshop 5 \\
\hline $\begin{array}{l}\text { Irrigation } \\
\text { reduces poverty }\end{array}$ & $\begin{array}{l}\text { Well-constructed } \\
\text { irrigation reduces } \\
\text { poverty }\end{array}$ & $\begin{array}{l}\text { Irrigation might reduce } \\
\text { poverty in low-lying areas } \\
\text { with already low poverty } \\
\text { but not in mountainous } \\
\text { areas with high poverty }\end{array}$ \\
\hline $\begin{array}{l}\text { Irrigation } \\
\text { increases } \\
\text { agricultural } \\
\text { production }\end{array}$ & $\begin{array}{l}\text { Well-constructed } \\
\text { irrigation increases } \\
\text { production/income }\end{array}$ & $\begin{array}{l}\text { Irrigation increases farm } \\
\text { income }\end{array}$ \\
\hline $\begin{array}{l}\text { Hydropower } \\
\text { causes riverbank } \\
\text { erosion }\end{array}$ & $\begin{array}{l}\text { Well-managed } \\
\text { hydropower will } \\
\text { increase dry-season } \\
\text { flows }\end{array}$ & $\begin{array}{l}\text { Hydropower increases } \\
\text { migration into urban } \\
\text { areas }\end{array}$ \\
\hline $\begin{array}{l}\text { Industries pollute } \\
\text { water }\end{array}$ & $\begin{array}{l}\text { Well-managed } \\
\text { hydropower will not } \\
\text { decrease downstream } \\
\text { flows }\end{array}$ & $\begin{array}{l}\text { Some districts should } \\
\text { focus on agricultural } \\
\text { development, others on } \\
\text { industrial development }\end{array}$ \\
\hline $\begin{array}{l}\text { Water pollution } \\
\text { decreases fish } \\
\text { stocks }\end{array}$ & $\begin{array}{l}\text { Hydropower } \\
\text { accelerates } \\
\text { urbanization }\end{array}$ & $\begin{array}{l}\text { Small-scale irrigation } \\
\text { more effective, in } \\
\text { particular because of } \\
\text { increasing urbanization }\end{array}$ \\
\hline
\end{tabular}

\section{The Tonle Sap, Cambodia}

The research focus in the Tonle Sap was designed in collaboration with the Tonle Sap Authority, and (quasi) government agency the Supreme National Economic Council. The Tonle Sap Authority has a mandate to oversee the design of Master Development plan for the lake and environs. The visioning was conducted in the same iterative process as described for the Nam Ngum Basin (Foran et al. 2013) with provincial representatives of affected villages and regions, civil society (Buddhist scholars and NGOs), decision makers, and influencers from ministries managing natural resources, agriculture and fisheries, energy and planning, and staff from the Tonle Sap Authority.

Key characteristics of the Tonle Sap visions include the following:

- Upper and lower Mekong River countries cooperate on water management;

- Restore and control water flow, prevent the collapse of banks;

- Sustainable management, conservation, and development;

- Conserved inundated forest and fish populations;

- Irrigation system constructed;

- Enhanced cultivation through better utilization of land and water;

- Policies to sustain agriculture and fishing sectors (marketing, irrigation);
- Expand cultivation area by accelerating unexploded ordnance clearance;

- Promote community production of seeds and quality products.

The third and fourth workshops (fourth step of the ChaRL framework) introduced scientific evidence related to the further development options for the Tonle Sap, considering upstream construction of hydropower dams, altered hydrological regime and sediment flux, possible abstractions and diversions for irrigation, and climate change. First, the hydrological results were presented. The debate was mainly concerned with the extent of the flood pulse change (Keskinen et al. 2011) and what this means for development options, such as rice cultivation. Second, comparisons of the 1998-2008 census data were presented, revealing a substantial youth surge, predicted to add 430,000 young people entering the labor market over the next eight years. The development of new employment opportunities in the Tonle Sap region represents a substantial additional policy challenge to the management of the Tonle Sap (Keskinen et al. 2013). Third, results from a household survey were presented. The survey relied on the same random sampling regime of 1000 households and a Khmer translation of the survey instrument used in the Nam Ngum Basin. Four results were most debated.

First, survey results did not confirm that fishing is still a major livelihood activity in the Tonle Sap. Only households in Kampung Chhnang, one of the six Tonle Sap provinces, reported fishing as their most important livelihood activity. Alternatively, rice cultivation was nominated for all provinces as the most important household livelihood activity. This should not overshadow the relevance of fish stocks as a second or third livelihood activity for subsistence. However, workshop participants expected fishing to be a more relevant source of household livelihoods. Second, offfarm activities generate more household income than on-farm activities. Third, the capacity and willingness/ability to adapt to future livelihood disruption is low compared with the Nam Ngum Basin, revealing high levels of potential vulnerability. For instance, when presented with a future collapse of fish stocks, $90 \%$ of those households who rely on fishing as a primary livelihood activity, would not change their livelihood, nor would they migrate elsewhere. Fourth, the establishment of new industries in the Tonle Sap area would have different effects on provincial poverty, largely because of the difference in the willingness and capacity to change livelihood activities. Participants expected much higher willingness to adapt, in particular intentions to migrate into other Mekong countries.

The final set of results presented utilized the Mersim model (Smajgl et al. 2013). The simulation of livelihood-related household behaviors and their feedbacks with environmental variables revealed surprising diversity. For the control benchmark we assumed unchanged livelihood conditions, while for the scenario we assumed halved fish stocks coinciding with expanded industry employment. Figure 5 illustrates the simulation results as two poverty maps. Village locations are depicted with square markers. Increasing red pigment in the village markers indicates higher levels of poverty. The maps depict a representative simulation run for the first of December. In some provinces poverty declines in response to the scenario assumptions whereas 
Fig. 5. Poverty maps for the Tonle Sap for a representative benchmark (left) and scenario (right) run emerging from the Mersim model. Village locations are marked with increasing levels of red indicating higher levels of poverty.

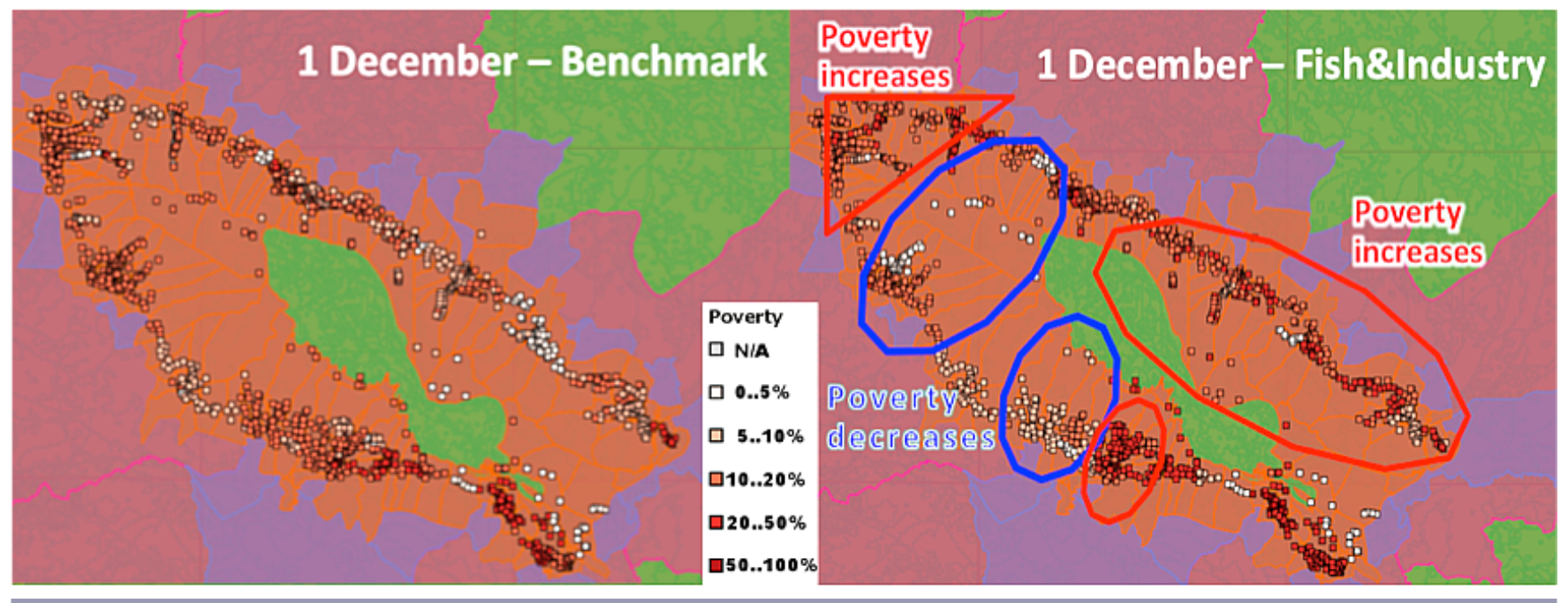

in others poverty increases. The response emphasizes the differences in dependency on fish stocks combined with differences in households' willingness to take on alternative paid labor.

Figure 5 is representative for a three month period in which poverty levels are historically low. During the remaining nine months of historically higher poverty levels, the scenario assumptions have no influence on simulated poverty levels. This insight of temporal and spatial diversity was a surprise to most participants. These responses and all belief-type statements were recorded during the break-out group discussions of all workshops. Table 3 lists the most relevant beliefs from the Tonle Sap process.

In the final step of the ChaRL framework, possibilities were identified to challenge existing beliefs by research results. In the Tonle Sap case study, the most relevant science-belief contrasts related to adaptation potential among households and the heterogeneity within the Tonle Sap area.

\section{DISCUSSION}

\section{Transboundary analysis of cross-sector impacts}

The transformational change guided by development investments will necessarily trigger trade-offs between water, food, and energy security as well as between different social groups. The decisionmaking situation in the Nam Ngum Basin is likely to have downstream effects because water flow and flood pulse will be affected, in particular as it coincides with developments in other parts of Lao PDR, upstream in Yunnan, and downstream in Vietnam, Thailand, and Cambodia. Participants in the Tonle Sap case study perceived this uncertainty as of major importance for the future of the Tonle Sap and, thereby, critical for understanding the effectiveness of possible interventions. The hydrological impacts are expected to significantly impact the Tonle Sap flood pulse, leading to delayed, shorter, and smaller floods and higher dry season water levels (Keskinen et al. 2011). Consequently, at least $18 \%$ of the current flood plain will be permanently
Table 3. Beliefs recorded during the workshop process around the Tonle Sap, Cambodia.

\begin{tabular}{|c|c|c|}
\hline Workshops $1 \& 2$ & Workshops $3 \& 4$ & Workshop 5 \\
\hline $\begin{array}{l}\text { Irrigation increases } \\
\text { production \& } \\
\text { income }\end{array}$ & $\begin{array}{l}\text { Farm consolidation } \\
\text { will increase } \\
\text { household income }\end{array}$ & $\begin{array}{l}\text { Labor will migrate } \\
\text { from agriculture to } \\
\text { industry }\end{array}$ \\
\hline $\begin{array}{l}\text { Integrated mixed } \\
\text { agriculture increases } \\
\text { farm income }\end{array}$ & $\begin{array}{l}\text { Farm consolidation } \\
\text { will reduce household } \\
\text { income and increase } \\
\text { social conflict }\end{array}$ & $\begin{array}{l}\text { Policies have to } \\
\text { account for high } \\
\text { diversity of } \\
\text { communities in Tonle } \\
\text { Sap }\end{array}$ \\
\hline $\begin{array}{l}\text { Collapsing fish } \\
\text { stocks will cause } \\
\text { emigration into } \\
\text { urban areas }\end{array}$ & $\begin{array}{l}\text { If fish stocks collapse } \\
\text { people will emigrate to } \\
\text { other countries }\end{array}$ & $\begin{array}{l}\text { Migration potential in } \\
\text { Tonle Sap rather low }\end{array}$ \\
\hline $\begin{array}{l}\text { With population } \\
\text { growth comes } \\
\text { overfishing }\end{array}$ & $\begin{array}{l}\text { If fish stocks collapse } \\
\text { people will take on } \\
\text { paid labor in } \\
\text { industries }\end{array}$ & $\begin{array}{l}\text { Hydropower reduces } \\
\text { fish stocks in the Tonle } \\
\text { Sap }\end{array}$ \\
\hline $\begin{array}{l}\text { Deforestation } \\
\text { decreases water } \\
\text { levels }\end{array}$ & $\begin{array}{l}\text { Industrialization will } \\
\text { accelerate migration }\end{array}$ & $\begin{array}{l}\text { Industry employment } \\
\text { in some districts more } \\
\text { beneficial than in } \\
\text { others }\end{array}$ \\
\hline
\end{tabular}

submerged, while $4-23 \%$ will no longer be flooded because of the reduced flood peak (Keskinen et al. 2011). Flow-on effects of an altered flood pulse and the delivery of nutrients will have deleterious consequences for current livelihoods, in particular fishing (Ziv et al. 2012, Lamberts 2013), and are likely to accelerate industrialization, migration, and urbanization, which contribute to the increasing demand for electricity (Foran 2013). The tradeoff in the water-food-energy nexus would put additional pressure on Cambodia to pursue their own plan to develop more hydropower, in particular along the Mekong mainstream (Foran 2013). Flow-on effects from such a decision on household nutrition and livelihoods in Cambodia have been stated to be 
devastating (Bouapao 2013, Pech 2013). That said, the Tonle Sap Lake and environs will also be affected by very local investments in irrigation, dykes, canals, and roads (Baran et al. 2007).

In addition to the hydrology-driven upstream-downstream perspective, social-economic factors are likely to trigger downstream-upstream effects. For instance, currently, adaptation behavior in the Tonle Sap emphasizes the cultivation of rice. The irrigation debate in the Nam Ngum Basin is largely targeting rice cultivation. However, if taking into account the possible price effects of increased rice production in Cambodia, and similar targets in Thailand, Myanmar, and Vietnam, land-use planning in Lao PDR might be less inclined to invest in large-scale cultivation of rice. Participants in the Nam Ngum Basin perceived this economic feedback as a critical constraint for their planning. Similarly, expected migration due to livelihood losses, or insufficient employment creation, in Cambodia was discussed as well as political tension created by shifting water access. These political and social side-effects of spatial and temporal reallocation of water were perceived as key transboundary implications of upstream development.

\section{Assessing the impacts of the ChaRL framework}

\section{Amended beliefs}

Table 2 lists those beliefs most critical for the planning context of the Nam Ngum River Basin Committee. Three observations can be made. First, the "provide irrigation-reduce poverty" belief was clearly articulated until the last workshop. In the fifth workshop the majority of participants articulated the opposite belief, consistent with the poverty distribution modeling results. This indicates that the direct contrasting of the existing belief and the presented scientific evidence catalyzed an amended belief set. Second, beliefs elicited during workshop 5 represent a more refined perception of the diversity in the basin and potential consequences. This is a clear indicator for participants replacing generalizing heuristics with a systems understanding that reflects a more diverse Nam Ngum Basin. Third, those beliefs that did not get challenged remain unchanged, specifically those directly linked to hydropower (Table 2), providing an additional control for factors, excluded from the ChaRL process and unaccounted for, that potentially influenced changes in the reported fundamental beliefs.

Table 3 shows elicited beliefs for the workshop process in the Tonle Sap Lake. The same observations can be inferred for the Tonle Sap context. Here, the largest belief change links to migration potential and the capacity to reduce poverty by developing new industry employment. Generalizing beliefs were replaced by more refined and nuanced perceptions of the diversity in the Tonle Sap area after beliefs were challenged during the fifth workshop.

The ChaRL framework and its underpinning theories define the values that guide people's lives as the second critical psychological construct for evaluating impacts. According to Stern et al. (1999) changes in values and beliefs would lead to changes in norms, behavior, and subsequent decisions. The appraisal of the human values data was intended to detect differences in observed value orientations between the commencement of the ChaRL learning process (workshop 1: visions), the introduction of science results (workshop 4), and completion (workshop 5: challenged beliefs).
Orientations of human values

Table 1 summarizes the mean, variance, and Student's $t$ test results of the aggregated likert scale scores of individual scale items assigned to the biocentricity, openness to change, conservativeness, altruism, and egocentricity value constructs. The variable sum supreme importance represents the number of scale items selected by respondents as of supreme importance.

The Tonle Sap workshop $1(\mathrm{n}=17)$ mean scores were significantly higher $(\alpha=0.05)$ compared with workshop $4(n=29)$ of all aggregated scale items (except the egocentric scale). The difference is due to a significant reduction in the mean number of scale items scored as "of supreme importance" in workshop $4($ mean $=4.72)$ compared with workshop 1 (mean $=12.00)$. The increased standard deviation of significantly different summed scales observed in workshop 4 (except the egocentric scale) indicates that, relative to workshop 1, respondents were increasingly selective and discriminating in assigning relative scale item importance. This confirms the belief-related results suggesting a more diversified understanding of the Tonle Sap.

There were no significant differences in the aggregated scale items $(\alpha=0.05)$ between the Nam Ngum Basin workshops $1(n=20)$ and $5(\mathrm{n}=27)$. However, the Nam Ngum workshop $4(\mathrm{n}=21)$ mean scores of the Biocentric $(\alpha=0.05)$ and Conservative $(\alpha=$ 0.10 ) aggregated scales were significantly higher than workshop 5. Consistent with the Tonle Sap results, the difference is due to a significant reduction in the mean number of scale items scored as of supreme importance in workshop $5($ mean $=3.70)$ compared with workshop 4 (mean $=6.10)$. Similar to the Tonle Sap, these results are consistent with the elicited changes in beliefs, suggesting a better understanding of the diversity in the Nam Ngum Basin.

Relatively large changes in mean difference in the Tonle Sap case study were observed for the Sum supreme importance (7.28) and Conservative (2.20) and Altruism (2.17) value scales compared to the Open to change scale (1.68). A moderate change was associated with the Biocentric scale (1.94). The mean differences observed in significantly different scales in the Nam Ngum are relatively small compared with the Tonle Sap. There is no significant change for the remaining scale comparisons.

In summary a detectable and statistically significant amendment in the value orientation of participants occurred during the ChaRL workshop sequence. A decrease in the mean scores for all the value scales, a general increase in the variance of scores and an increased differentiation by respondents within and between the human value scale items are consistent observations for both the Tonle Sap Lake and Nam Ngum Basin. That is, participants in latter workshops were more selective and displayed a reduced generalization that all values are important.

The above suggests that the implementation of the ChaRL-based participatory process in the Nam Ngum Basin and the Tonle Sap influenced beliefs and values of critical decision makers and decision influencers. This evaluation focus is limited to the individual participants and the length of the ChaRL process. When extending the view to the relevant decisions a few observations can already be made. The Nam Ngum River Basin Committee Secretariat changed their development plan and replaced large-scale irrigation schemes by selected small-scale 
irrigation schemes in upper districts and a revised irrigation approach to the Vientiane plain. Additionally, four new river basin organizations in Lao PDR, currently being established, will implement the ChaRL process as a participatory planning process developing visions and contesting existing assumptions by scientific evidence. In synthesis, the monitoring and evaluation results suggest that development investments of over US\$300m have been guided and redirected to further improve poverty alleviation outcomes in the Nam Ngum Basin. This came at a cost of about US\$450,000 for each implementation of the ChaRL process. So far, the Tonle Sap process has not resulted in changed decisions or development plans. However, decision makers have acknowledged the need to revise current planning to better match the diverse conditions of districts and environs around the Tonle Sap Lake. That said, we will continue to monitor the formal Tonle Sap planning process to see what, if any, changes the ChaRL process has had on design and implementation.

\section{Comparing results with other participatory approaches}

Comparing outcomes of implementing the ChaRL framework with other participatory methods is difficult. Many participatory approaches do not provide a specific and replicable protocol, or sequence of activities, and most do not conduct an evaluation beyond a qualitative description of contextual observations. These evaluation-related aspects constitute advantages of the ChaRL framework because the principle sequence of steps is replicable and follows validated psychological foundations. Additionally, the psychological constructs are measurable, allowing practitioners to trace changes in beliefs, attitudes, and values over time in respect to particular methods used during the process. Those participatory approaches that explicitly addressed the evaluation challenge revert mostly to interview-based ex post evaluations, which introduce perception-related uncertainties. ChaRL, however, allows for ongoing monitoring and thereby an adjustment of the methods deployed.

Perez et al. (2014) provide the most notable effort to formalize evaluation for one particular participatory modeling approach, companion modeling. Perez and colleagues largely focused on facilitating a better understanding of different points of view among different decision makers. Thus, the evaluation focused on the coordination mechanism, eliciting how perspectives have changed. It is important to reemphasize that the benchmark for companion modeling is largely the mental model of other stakeholders (in a few cases also facilitated through explicit shared visions as in d'Aquino and Bah 2013), while for ChaRL the benchmarks are created via a compendium of local knowledge, scientific methods, and empirical data.

The evaluation of mediated modeling (van den Belt 2004) is largely focused on how well the (system dynamics) model resembles stakeholders' perceptions and what learning this process facilitated in the research team. However, a key criterion for mediated modeling is consensus among participants.

Both participatory modeling approaches have been repeatedly applied to various decision-making contexts and positive impacts on decision-making arenas are documented (van den Belt 2004, Perez et al. 2014). However, in most cases it seems difficult to distinguish the relevance of the participatory process because the engagement is only one influence among many in an often very dynamic environment. The advantage of the ChaRL framework is that evidence for participants' learning is elicited during the engagement, allowing the stages when beliefs and values change to be identified. Identifying incremental change is necessary because ChaRL aims to facilitate systems learning among participants, which requires a different evaluation approach than engagement processes that aim for conflict resolution or consensus building.

\section{Discursive and structural challenges}

Two core assumptions underpin the ChaRL methodology. First, development decisions are complex, unstructured, power-laden, and thus, in a given national or regional political economy, biased in terms of which narratives dominate and whose interests are consistently privileged. Second, despite these political-economic challenges, the ChaRL process facilitates a detectable revision of the means-ends rationality of development decision making.

The reported methods deploy science to mediate learning among small groups of midlevel policy advisors. Some readers may find the methodology, as implemented, to be too elite-oriented, technocratic, and hence not sufficiently inclusive of marginalized actors. A stronger criticism is that the approach is too optimistic about the potential of amended individual beliefs leveraging change in interest-laden development strategies (Molle et al. 2009, Foran 2015).

In reporting on a methodology that involves voluntary, microsocial, deliberative interactions, we do not mean to downplay structural power asymmetries and the bias posed by development metanarratives. Institutionalizing more democratic, deliberative processes in development planning runs against the formidable forces of an extant political economy. Combined these lines of criticism suggest that the next iterations of this sciencebased Habermasian approach include an expanded representation of decision-affected communities and nonstate actors.

\section{CONCLUSION}

Facilitating a learning process for decision makers and decision influencers across multiple levels in the rapidly transforming Mekong region requires methods to jointly address the competing values, complexity, and uncertainty associated with climate change and development (O'Brien and Leichenko 2000). An equally sophisticated process design is also required to communicate uncertainties and complexity, and identify and replace misguiding beliefs.

This paper described an example implemented in the Mekong region, employing a design protocol for participatory processes capable to address existing complexities and uncertainties. The design protocol is based on the Challenge and Reconstruct Learning (ChaRL) framework. The framework was designed to establish and maintain an effective science-policy interface despite high complexity, factual uncertainty, and highly contested values. The primary objective of the ChaRL learning framework was to facilitate system-focused learning by decision makers and decision influencers. Such learning is largely understood as fundamental for successful adaptation (Adger et al. 2005). Core constructs of the ChaRL framework are visions and beliefs, where shared visions are elicited as narratives of desirable, plausible futures constructed in future envisioning workshops. Beliefs are formally recorded as causal statements. According to Stern et al. (1999) changes in values and beliefs lead to changes in behavior 
and decisions. We provide evidence that participants amended their beliefs and values during the course of the ChaRL process. Observed changes in actual decision making affecting the Nam Ngum River Basin and the Tonle Sap provide additional evidence. However, if cross-sectoral deliberation is rarely practiced, the direct challenging of extant and politically protected beliefs can be too confrontational, as experienced in Vietnam's Mekong Delta. In these cases, subtler approaches to establish doubt among decision makers and to depoliticize the debate must be found.

The cautious elicitation of existing beliefs and the employment of mixed methods were critical in achieving learning among decision makers and decision influencers from the Nam Ngum River Basin and the Tonle Sap Lake. Most importantly, the case study evidence highlights that learning success is critically dependent on the research process assigning the locus of process control to decision makers to promote effective and widely endorsed participation throughout the research process (Barreteau et al. 2010, Smajgl 2010).

Explicitly addressing multiple governance levels was a central design consideration because many decisions in the wider Mekong region are determined at a national or subnational level while some of these decisions are likely to have implications for the wider Mekong region. As a corollary, this work focused on crossscale and transboundary dynamics of impending development investments and decisions with the potential to transform the wider Mekong region. Understanding ex ante and ex post system properties of a potential transformation was critical to avoid the substantial social costs associated with persistent, maladaptive strategies. Comparing the likely consequences, and estimates of associated error measurements, of pending decisions with desired outcomes is a central and essential aspect of potential transformations evaluated by the ChaRL framework.

The learning-focused ChaRL framework measured and facilitated changes in existing beliefs, by tracing the fate of new knowledge introduced by a specific research process and capturing attendant changes in value and belief orientations. For instance, irrigation has been viewed as a panacea for poverty alleviation, manifest as a generalized policy response promoting investments in large-scale irrigation schemes to jointly meet the challenges of climate change and achieve development objectives (Ward and Kaczan 2014). The results reported in this paper challenged the veracity of the irrigation claim for the Nam Ngum Basin. Similar generalizations were successfully challenged regarding proposed payments for ecosystem services in Xishuangbanna Yunnan and the construction of sea dikes in the Mekong Delta. Guiding stakeholders in formulating a less generalized understanding of the impacts of available adaptation strategies is likely to improve the suitability of investments for different areas in the highly diverse wider Mekong region.

In conclusion, the experiences in the Mekong region can be translated into insights and improvements for future implementations of ChaRL or similar participatory process protocols. First, the ChaRL framework seems promising in achieving and monitoring learning among stakeholders. Second, in complex unstructured decision-making situations, agent-based modeling in conjunction with household surveys provides an effective method for challenging existing beliefs. Third, the absence of democratic structures requires the development of subtler, less confrontational presentation of belief-science contrasts. Fourth, effectiveness of the ChaRL framework depends on high retention rates, otherwise a sufficient number of delegates in the final workshop will not identify with the visions created in workshops 1 and 2 .

Responses to this article can be read online at: http://www.ecologyandsociety.org/issues/responses. $\mathrm{php} / 7421$

\section{Acknowledgments:}

The authors thank the DFAT-CSIRO Research for Development Alliance and the CSIRO Climate Change Adaptation Flagship for financial and operational support.

\section{LITERATURE CITED}

Adger, W. N., N. W. Arnell, and E. L. Tompkins. 2005. Successful adaptation to climate change across scales. Global Environmental Change 15(2):77-86. http://dx.doi.org/10.1016/j.gloenvcha.2004.12.005

Asian Development Bank (ADB). 2011. The Greater Mekong subregion economic cooperation program strategic framework 2012-2022. ADB, Manila, The Philippines.

Asian Development Bank (ADB). 2012. GMS Atlas of the environment. Second Edition. ADB, Manila, The Philippines.

Asian Development Bank and United Nations Environment Programme (ADB and UNEP). 2004. Greater Mekong subregion atlas of the environment. ADB and UNEP, Manila, The Philippines.

Baird, I. G. 2014. Political memories of conflict, economic land concessions, and political landscapes in the Lao People's Democratic Republic. Geoforum 52:61-69. http://dx.doi. org/10.1016/j.geoforum.2013.12.012

Baran, E., P. Starr, and Y. Kura. 2007. Influence of built structures on Tonle Sap fisheries. ADB TA 4669-CAM. World Fish Center, Phnom Penh, Cambodia.

Barreteau, O., P. W. G. Bots, and K. A. Daniell. 2010. A framework for clarifying "participation" in participatory research to prevent its rejection for the wrong reasons. Ecology and Society 15(2): 1. [online] URL: http://www.ecologyandsociety.org/vol15/ iss2/art1/

Bartlett, R., J. Baker, G. Lacombe, S. Douangsavanh, and M. Jeuland. 2012. Analyzing economic trade-offs of water use in the Nam Ngum River Basin, Lao PDR. Duke University Environmental Economics Working Paper Series, Working Paper EE 12-10. Duke University, Durham, North Carolina, USA.

Berkes, F., J. Colding, and C. Folke. 2003. Navigating socialecological systems: building resilience for complexity and change. Cambridge University Press, Cambridge, UK. http://dx.doi. org/10.1017/CBO9780511541957

Bouapao, L. 2013. Livelihoods and migration. Pages 143-178 in A. Smajgl and J. Ward, editors. The water-food-energy nexus in the Mekong Region: assessing development strategies considering 
cross-sectoral and transboundary impacts. Springer, New York, New York, USA. http://dx.doi.org/10.1007/978-1-4614-6120-3_5

Bousquet, F., C. Barnaud, O. Barreteau, F. Cernesson, P. Dumrongrojwatthana, L. C. Dung, B. Ekasingh, N. Gajaseni, C. T. Hoanh, C. LePage, W. Naivinit, P. Promburom, T. Raj Gurung, N. Ruankaew, and G. Trébuil. 2006. Companion modelling for resilient water management: stakeholders' perceptions of water dynamics and collective learning at the catchment scale. Pages 98-101 in France and the CGIAR: delivering scientific results for agricultural development. CGIAR Consortium, Montpellier, France.

Cash, D. W., W. C. Clark, F. Alcock, N. M. Dickson, N. Eckley, D. H. Guston, J. Jäger, and R. B. Mitchell. 2003. Knowledge systems for sustainable development. Proceedings of the National Academy of Sciences 100(14):8086-8091. http://dx.doi.org/10.1073/ pnas. 1231332100

Clay, E. J., and B. B. Schaffer, editors. 1986. Room for manoeuvre, an explanation of public policy in agriculture and rural development. Associate University Presses, Plainsboro, New Jersey, USA.

Cornwall, A. 2007. Buzzwords and fuzzwords: deconstructing development discourse. Development in Practice 7(4-5):471-484. http://dx.doi.org/10.1080/09614520701469302

Cornwall, A., and R. Jewkes. 1995. What is participatory research? Social Science and Medicine 41(12):1667-1676. http:// dx.doi.org/10.1016/0277-9536(95)00127-S

d'Aquino, P., and A. Bah. 2013. A participatory modeling process to capture indigenous ways of adaptability to uncertainty: outputs from an experiment in West African drylands. Ecology and Society 18(4): 16. http://dx.doi.org/10.5751/ES-05876-180416

Dore, J. 2003. The governance of increasing Mekong regionalism. Pages 405-440 in M. Kaosa-ard and J. Dore, editors. Social challenges for the Mekong region. White Lotus, Bangkok, Thailand.

Faucheux, S., G. Froger, and J.-F. Noël. 1995. What forms of rationality for sustainable development? Journal of SocioEconomics 24(1):169-209. http://dx.doi.org/10.1016/1053-5357 (95)90035-7

Foran, T. 2013. Impacts of natural resource-led development on the Mekong energy system. Pages 105-142 in A. Smajgl and J. Ward, editors. The water-food-energynexus in the Mekong Region: assessing development strategies considering cross-sectoral and transboundary impacts. Springer, New York, New York, USA. http://dx.doi.org/10.1007/978-1-4614-6120-3 4

Foran, T. 2015. Node and regime: interdisciplinary analysis of water-energy-food nexus in the Mekong region. Water Alternatives 8(1):655-674.

Foran, T., J. Ward, E. Kemp-Benedict, and A. Smajgl. 2013. Developing detailed foresight narratives: a participatory technique from the Mekong region. Ecology and Society 18(4): 6. http://dx.doi.org/10.5751/ES-05796-180406

Friend, R., and M. Moench. 2013. What is the purpose of urban climate resilience? Implications for addressing poverty and vulnerability. Urban Climate 6:98-113. http://dx.doi.org/10.1016/ j.uclim.2013.09.002
Funtowicz, S. O., and J. R. Ravetz. 1993. Science for the postnormal age. Futures 25(7):739-755. http://dx.doi.org/10.1016/0016-3287 (93)90022-L

Gasper, D., and R. Apthorpe. 1996. Introduction: discourse analysis and policy discourse. European Journal of Development Research 8:1-15. http://dx.doi.org/10.1080/09578819608426650

Gigerenzer, G., and P. M. Todd. 2001. Simple heuristics that make us smart. Oxford University Press, New York, New York, USA.

Grimm, V., U. Berger, D. L. DeAngelis, J. G. Polhill, J. Giske, and S. F. Railsback. 2010. The ODD protocol: a review and first update. Ecological Modelling 221(23):2760-2768. http://dx.doi. org/10.1016/j.ecolmodel.2010.08.019

Grimm, V., U. Berger, F. Bastiansen, S. Eliassen, V. Ginot, J. Giske, J. Goss-Custard, T. Grand, S. K. Heinz, G. Huse, A. Huth, J. U. Jepsen, C. Jørgensen, W. M. Mooij, B. Müller, G. Pe'er, C. Piou, S. F. Railsback, A. M. Robbins, M. M. Robbins, E. Rossmanith, N. Rüger, E. Strand, S. Souissi, R. A. Stillman, R. Vabø, U. Visser, and D. L. DeAngelis. 2006. A standard protocol for describing individual-based and agent-based models. Ecological Modelling 198(1-2):115-126. http://dx.doi.org/10.1016/j.ecolmodel.2006.04.023

Größler, A. 2004. A content and process view on bounded rationality in system dynamics. Systems Research and Behavioral Science 21:319-330. http://dx.doi.org/10.1002/sres.646

Gunderson, L. H., and C. S. Holling. 2001. Panarchy: understanding transformations in human and natural systems. Island Press, Washington, D.C., USA.

Habermas, J. 2005. Concluding comments on empirical approaches to deliberative politics. Acta Politica 40(3):384-392. http://dx.doi.org/10.1057/palgrave.ap.5500119

Hirsch, P., and K. Jensen. 2006. National interests and transboundary water governance in the Mekong. Australian Mekong Resource Centre, University of Sydney, Sydney, Australia.

Hisschemöller, M., and R. Hoppe. 1996. Coping with intractable controversies: the case for problem structuring in policy design and analysis. Knowledge and Policy 8(4):40-60. http://dx.doi. org/10.1007/BF02832229

Hoppe, R. 2005. Rethinking the science-policy nexus: from knowledge utilization and science technology studies to types of boundary arrangements. Poiesis \& Praxis 3:199-215. http://dx. doi.org/10.1007/s10202-005-0074-0

International Centre for Environmental Management (ICEM). 2013. USAID Mekong ARCC climate change impact and adaptation: main report. Prepared for the United States Agency for International Development. ICEM, Hanoi, Vietnam.

International Union for Conservation of Nature (IUCN), International Water Management Institute (IWMI), Ramsar Convention Bureau, and World Resources Institute (WRI). 2003. Water Resources eAtlas. IUCN, IWMI, Ramsar Convention Bureau, WRI, Washington, D.C., USA.

Jeuland, M., J. Baker, R. Bartlett, and G. Lacombe. 2014. The costs of uncoordinated infrastructure management in multireservoir river basins. Environmental Research Letters 9 (10):105006. http://dx.doi.org/10.1088/1748-9326/9/10/105006 
Kahneman, D. 2011. Thinking fast and slow. Farrar, Straus and Giroux, New York, New York, USA.

Keskinen, M., M. Kummu, A. Salmivaara, P. Someth, H. Lauri, H. de Moel, P. Ward, and P. Sokhem. 2011. Exploring Tonle Sap futures: baseline results from hydrological and livelihood analyses. Aalto University and $100 \mathrm{Gen}$ Ltd. with Hatfield Consultants Partnership, VU University Amsterdam, EIA Ltd., and Institute of Technology of Cambodia, Phnom Penh, Cambodia.

Keskinen, M., M. Kummu, A. Salmivaara, P. Someth, H. Lauri, H. de Moel, P. Ward, and P. Sokhem. 2013. Tonle Sap now and in the future? Final Report of the Exploring Tonle Sap Futures study. Water \& Development Publications WD-11. Aalto University and 100Gen Ltd. with Hatfield Consultants Partnership, VU University Amsterdam, EIA Ltd., and Institute of Technology of Cambodia, in partnership with Tonle Sap Authority and Supreme National Economic Council, Phnom Penh, Cambodia.

Kollock, P. 1998. Social dilemmas: the anatomy of cooperation. Annual Review of Sociology 24:183-214. http://dx.doi. org/10.1146/annurev.soc.24.1.183

Kummu, M., and J. Sarkkula. 2008. Impact of the Mekong River flow alteration on the Tonle Sap flood pulse. AMBIO 37 (3):185-192. http://dx.doi.org/10.1579/0044-7447(2008)37[185: IOTMRF]2.0.CO;2

Lacombe, G., S. Douangsavanh, J. Baker, C. T. Hoanh, R. Bartlett, M. Jeuland, and C. Phongpachith. 2014. Are hydropower and irrigation development complements or substitutes? The example of the Nam Ngum River in the Mekong Basin. Water International 39(5):649-670. http://dx.doi. org/10.1080/02508060.2014.956205

Lamberts, D. 2013. The role and significance of the flood pulse in the functioning and management of the Tonle Sap ecosystem, Cambodia. Dissertation. KU Leuven, Leuven, Belgium. [online] URL: https://lirias.kuleuven.be/handle/123456789/398507

Laswell, H. D. 1971. A re-view of policy sciences. Elsevier, New York, New York, USA.

Lauri, H., H. de Moel, P. J. Ward, T. A. Räsänen, M. Keskinen, and M. Kummu. 2012. Future changes in Mekong River hydrology: impact of climate change and reservoir operation on discharge. Hydrology and Earth System Sciences 16:4603-4619. http://dx.doi.org/10.5194/hess-16-4603-2012

Leach, M., R. Mearns, and I. Scoones. 1999. Environmental entitlements: dynamics and institutions in community-based natural resource management. World Development 27(2):225-247. http://dx.doi.org/10.1016/S0305-750X(98)00141-7

Lebel, L., J. M. Anderies, B. Campbell, C. Folke, S. Hatfield Dodds, T. P. Hughes, and J. Wilson. 2006. Governance and the capacity to manage resilience in regional social-ecological systems. Ecology and Society 11(1): 19. [online] URL: http://www. ecologyandsociety.org/vol11/iss1/art19/

Liu, S., P. Lu, D. Liu, and P. Jin. 2007. Pinpointing source of Mekong and measuring its length through analysis of satellite imagery and field investigations. Geo-spatial Information Science 10(1):51-56. http://dx.doi.org/10.1007/s11806-007-0011-6
Maru, Y. T. 2010. Resilient regions: clarity of concepts and challenges to systemic measurement. CSIRO Working Paper Series. CSIRO, Canberra, Australia.

McIntyre, A. 2008. Participatory action research. Sage, Thousand Oaks, California, USA. http://dx.doi.org/10.4135/9781483385679

Mekong River Commission (MRC). 2011. Planning atlas of the Lower Mekong Basin. Mekong River Commission, Vientiane, Lao PDR.

Mingsarn, K., and J. Dore, editors. 2003. Social challenges for the Mekong region. White Lotus, Bangkok, Thailand.

Molle, F., T. Foran, and P. Floch. 2009. Introduction: changing waterscapes in the Mekong region: historical background and context. Pages 1-19 in F. Molle, T. Foran, and M. Käkönen, editors. Contested waterscapes in the Mekong region: hydropower, livelihoods and governance. Earthscan, London, UK.

O’Brien, K. L., and R. M. Leichenko. 2000. Double exposure: assessing the impacts of climate change within the context of economic globalization. Global Environmental Change 10 (3):221-232. http://dx.doi.org/10.1016/S0959-3780(00)00021-2

Ostrom, E. 2010. Polycentric systems for coping with collective action and global environmental change. Global Environmental Change 20(4):550-557. http://dx.doi.org/10.1016/j.gloenvcha.2010.07.004

Pech, S. 2013. Water sector analysis. Pages 19-60 in A. Smajgl and J. Ward, editors. The water-food-energy nexus in the Mekong Region: assessing development strategies considering cross-sectoral and transboundary impacts. Springer, New York, New York, USA. http://dx.doi.org/10.1007/978-1-4614-6120-3 2

Perez, P., S. Aubert, W. Daré, R. Ducrot, N. Jones, J. Queste, G. Trébuil, and A. Van Paassen. 2014. Assessment and monitoring of the effects of the ComMod approach. Pages 155-187 in M. Étienne, editor. Companion modelling: a participatory approach to support sustainable development. Editions Quae, Versailles, France. http://dx.doi.org/10.1007/978-94-017-8557-0_7

Pielke, Jr., R. A. 2007. The honest broker: making sense of science in policy and politics. Cambridge University Press, Cambridge, UK. http://dx.doi.org/10.1017/CBO9780511818110

Schwartz, S. H. 1992. Universals in the content and structure of values: theory and empirical tests in 20 countries. Pages 1-65 in M. Zanna, editor. Advances in experimental social psychology. Academic Press, New York, New York, USA.

Schwartz, S. H. 1994. Are there universal aspects in the structure and contents of human values? Journal of Social Issues 50 (4):19-45. http://dx.doi.org/10.1111/j.1540-4560.1994.tb01196.x

Scott, J. C. 2009. The art of not being governed: an anarchist history of upland Southeast Asia. Yale University Press, New Haven, Connecticut, USA.

Sen, A. 2009. The idea of justice. Belknap Press of Harvard University Press, Cambridge, Massachusetts, USA.

Shore, C., and S. Wright. 1997. Anthropology of policy: critical perspectives on governance and power. Routledge, London, UK. 
Simon, H. A. 1972. Theories of bounded rationality. Pages in R. Radner and C. B. Radner, editors. Decision and organisation. North Holland, Amsterdam, The Netherlands.

Smajgl, A. 2003. Conceptual and institutional aspects in implementing an emissions trading scheme. Pages 327-336 in C. A. Brebbia and F. Patania, editors. Air Pollution XI - Eleventh International Conference on Modelling, Monitoring and Management of Air Pollution. WIT Press, Southampton, UK.

Smajgl, A. 2009. Accounting for multiple governance scales in integrated modelling and decision support. Pages 189-202 in W. Proctor, L. Van Kerkhoff and S. Hatfield Dodds, editors. Reflecting on integrated mission directed research: Learning from experience in environmental and natural resource management. CSIRO, Collingwood, Australia.

Smajgl, A. 2010. Challenging beliefs through multi-level participatory modelling in Indonesia. Environmental Modelling and Software 25(11):1470-1476. http://dx.doi.org/10.1016/j. envsoft.2010.04.008

Smajgl, A., S. Egan, M. Kirby, M. Mainuddin, J. Ward, and F. Kroon. 2013. The Mekong region simulation (Mersim) model Design Document. CSIRO Climate Adaptation Flagship, Townsville, Australia.

Smajgl, A., and J. Ward. 2013a. A framework to bridge science and policy in complex decision making arenas. Futures 52 (8):52-58. http://dx.doi.org/10.1016/j.futures.2013.07.002

Smajgl, A., and J. Ward, editors. 2013b. The water-food-energy nexus in the Mekong region. Springer, New York, New York, USA. http://dx.doi.org/10.1007/978-1-4614-6120-3

Sterk, B., P. Carberry, C. Leeuwis, C., M. K. van Ittersum, M. Howden, H. Meinke, H. van Keulen, and W. A. H. Rossing. 2009. The interface between land use systems research and policy: multiple arrangements and leverages. Land Use Policy 26 (2):434-442. http://dx.doi.org/10.1016/j.landusepol.2008.05.003

Stern, P. C., T. Dietz, T. Abel, G. A. Guagnano, and L. Kalof. 1999. A value belief norm theory of support for social movements: the case of environmental concern. Human Ecology Review 6:81-97.

Stern, P. C., T. Dietz, and G. A. Guagnano. 1998. A brief inventory of values. Educational and Psychological Measurement 58:984-1001. http://dx.doi.org/10.1177/0013164498058006008

Stirling, A. 2010. Keep it complex. Nature 468:1029-1031. http:// dx.doi.org/10.1038/4681029a

van den Belt, M. 2004. Mediated modelling: a system dynamics approach to environmental consensus building. Island Press, Washington, D.C., USA.

Van Zalinge, N., T. Nao, T. Touch, S. Tana, and L. Deap. 2000. Where there is water, there is fish? Cambodian fisheries issues in a Mekong River Basin perspective. Pages 37-48 in M. Ahmed and P. Hirsch, editors. Common property in the Mekong: issues of sustainability and subsistence. ICLARM Studies and Reviews, Penang, Malaysia.

Voinov, A., and F. Bousquet. 2010. Modelling with stakeholders. Environmental Modelling and Software 25(11):1268-1281. http:// dx.doi.org/10.1016/i.envsoft.2010.03.007
Walker, B., C. S. Holling, S. R. Carpenter, and A. Kinzig. 2004. Resilience, adaptability and transformability in social-ecological systems. Ecology and Society 9(2): 5. [online] URL: http://www. ecologyandsociety.org/vo19/iss2/art5/

Ward, J., and D. Kaczan. 2014. Challenging hydrological panaceas: water poverty governance accounting for spatial scales in the Niger River Basin. Journal of Hydrology 519:2501-2514. http://dx.doi.org/10.1016/j.jhydrol.2014.05.068

Ward, J., and H. Poutsma. 2013. The compilation and summary analysis of Tonle Sap Household livelihoods: exploring Tonle Sap Futures Project. CSIRO Climate Adaptation Flagship, Canberra, Australia.

Water Resources and Environment Administration (WREA). 2008. Nam Ngum River Basin Profile. Prepared by the Lao PDR Water Resources and Environment Administration under the Nam Ngum River Basin Development Sector Project, supported by the Asian Development Bank (Loan 1933-LAO) and Agence Francaise de Developpement (Grant CLA 1048 01H). WREA, Vientiane Laos PDR.

Winter, G. 1966. Elements for a social ethic: scientific perspectives on social process. MacMillan, New York, New York, USA.

World Health Organization (WHO). 2011. Process of translation and adaptation of instruments. WHO, Geneva, Switzerland.

Ziv, G., E. Baran, S. Nam, I. Rodríguez-Iturbe, and S. A Levin. 2012. Trading-off fish biodiversity, food security, and hydropower in the Mekong River Basin. Proceedings of the National Academy of Sciences 109(15):5609-5614. http://dx.doi.org/10.1073/ pnas. 1201423109

Zomer, R. J., A. Trabucco, M. Wang, R. Lang, H. Chen, M. J. Metzger, A. Smajgl, P. Beckschäfer, and J. Xu. 2014. Environmental stratification to model climate change impacts on biodiversity and rubber production in Xishuangbanna, Yunnan, China. Biological Conservation 170:264-273. http://dx.doi. org/10.1016/j.biocon.2013.11.028 